\title{
Wetland Technologies for Nursery and Greenhouse Compliance with Nutrient Regulations
}

\author{
Sarah A. White ${ }^{1}$ \\ School of Agricultural, Forest, and Environmental Sciences, Clemson University, E-143 Poole Agric. \\ Center, Clemson, SC 29634-0310
}

Additional index words. eutrophication, floating treatment wetlands, nitrogen, phosphorus, subsurface-flow wetlands, surface-flow wetlands, total maximum daily load

\begin{abstract}
The need to protect our water resources and increasing public awareness of the importance of cleaner water for ecological and human health reasons are driving regulations limiting nutrient release from traditionally exempt, non-point source agricultural contributors. Modification of production practices alone may not be adequate to meet regulated nutrient criterion limits for irrigation and stormwater runoff entering surface waters. Three constructed wetland technologies are well suited to help agricultural producers meet current and future regulations. The first two technologies, surface- and subsurface-flow constructed wetlands, have been in use for over 40 years to cleanse various types of wastewater, whereas floating treatment wetlands are an emerging remediation technology with potential for both stormwater and agricultural runoff treatment applications. The mechanisms driving removal of both nitrogen $(\mathrm{N})$ and phosphorus $(\mathrm{P})$ in constructed wetland systems are discussed. Surface-flow constructed wetlands remediate $N$ contaminants from both container nursery and greenhouse production wastewater, whereas $P$ remediation is variable and tied most closely to active plant growth as the constructed wetland ages. Subsurface-flow constructed wetlands effectively remediate $\mathrm{N}$ from production wastewater and can be tailored to increase consistency of $P$ remediation through selection of $P$-sorbing root-bed substrates. Floating treatment wetlands effectively remediate both $N$ and $P$ with a designed surface area of a pond covered depending on the target effluent concentration or regulated total maximum daily load. The choice of treatment technology applied by growers to meet regulated water quality targets should be based on both economic and site-specific considerations.
\end{abstract}

\section{ECOLOGICAL IMPACTS OF NUTRIENT ENRICHMENT}

As human population increases and distribution shifts from rural communities to urban centers, demand for water to support urban and industrial requirements will increase, reducing the amount and/or quality of water available for agriculture (Rosengrant and Ringler, 1998). The quality of many surface water sources is negatively impacted by nutrient contamination from both point and non-point source contributors [U.S. Environmental Protection Agency (EPA), 2013a]. When dissolved oxygen declines in a water body in response to increased primary productivity driven by nutrient enrichment, dead zones can form. Measures of water quality, such as low dissolved oxygen or increased primary productivity, become justification for regulatory action enforced at the city, state, and/or federal level in an effort to decrease nutrient enrichment of water bodies (Conley et al., 2009).

Nutrient enrichment, also called eutrophication, can be broadly defined as the process whereby water body productivity, both primary and secondary, increases in response to

Received for publication 27 Feb. 2013. Accepted for publication 24 Apr. 2013.

Special thanks to Drs. John Lea-Cox, John Majsztrik, and Don Merhaut for their critical review of an earlier draft of this manuscript.

This paper was part of the colloquium "Regulating Water Quality: Current Legislation, Future Impacts" held 1 Aug. 2012 at the ASHS Conference, Miami, FL, and sponsored by the Nursery Crops, Water Utilization and Management, Waste Utilization in Horticulture, and Floriculture Working Group.

${ }^{1}$ To whom reprint requests should be addressed; e-mail swhite4@clemson.edu. increased nutrient availability (Khan and Ansari, 2005; Wight and Welbourn, 2002). Primary productivity refers to the growth of organisms, typically photosynthetic flora but also cyanobacteria, that synthesize organic mass from inorganic materials (Elser et al., 2007), whereas secondary productivity refers to organisms that feed on primary producers. Eutrophication is a naturally occurring process in surface waters. A water body's progression from oligotrophic (less than 5 to $10 \mu \mathrm{g} \cdot \mathrm{L}^{-1} \mathrm{P}$, less than 250 to $600 \mu \mathrm{g} \cdot \mathrm{L}^{-1} \mathrm{~N}$, and 50 to $300 \mathrm{mg} \cdot \mathrm{m}^{-2} \cdot \mathrm{d}^{-1}$ carbon), to mesotropic (less than 10 to $30 \mu \mathrm{g} \cdot \mathrm{L}^{-1} \mathrm{P}, 300$ to $600 \mu \mathrm{g} \cdot \mathrm{L}^{-1}$ $\mathrm{N}$ ), and finally to eutrophic (greater than $30 \mu \mathrm{g} \cdot \mathrm{L}^{-1} \mathrm{P}$, greater than $500 \mu \mathrm{g} \cdot \mathrm{L}^{-1} \mathrm{~N}$, and $1 \mathrm{~g} \cdot \mathrm{m}^{-2} \cdot \mathrm{d}^{-1}$ or greater carbon) depends on the normal nutrient status of the lake, geographical location, watershed size, and nutrient and rainfall inputs over time (Khan and Ansari, 2005; Lillie and Mason, 1983). Existing paradigms indicate that $\mathrm{P}$ is the nutrient limiting primary productivity in freshwater systems, whereas $\mathrm{N}$ limits productivity in estuarine, oceanic, and terrestrial systems (Conley, 2000). However, recent work raised questions regarding these paradigms, because both $\mathrm{N}$ and $\mathrm{P}$ appear to be equally limited in most freshwater systems, and the addition of both $\mathrm{N}$ and $\mathrm{P}$ to aquatic systems (whether freshwater or saltwater) results in synergistic increases in primary productivity (Elser et al., 2007). A "dual-nutrient-reduction strategy" limiting loading of both $\mathrm{N}$ and $\mathrm{P}$ into surface waters is needed to effectively control eutrophication (Conley et al., 2009).

\section{NUTRIENT CONCENTRATIONS IN PRODUCTION WASTEWATER}

The concentration of nutrients in container nursery (crops produced in open systems, without permanent cover) effluent can range from 0.1 to $135 \mathrm{mg} \cdot \mathrm{L}^{-1}$ nitrate-nitrogen $\left(\mathrm{NO}_{3}-\mathrm{N}\right)$ and 0.01 to $20 \mathrm{mg} \cdot \mathrm{L}^{-1}$ phosphatephosphorus $\left(\mathrm{PO}_{4}-\mathrm{P}\right)$ (Huett et al., 2005; Taylor et al., 2006). Runoff volumes from nursery container production areas can range from $3.9 \mathrm{~L} \cdot \mathrm{m}^{-2} \cdot \mathrm{d}^{-1}$ to $22.6 \mathrm{~L} \cdot \mathrm{m}^{-2} \cdot \mathrm{d}^{-1}$ or more, depending on irrigation delivery method, frequency, duration, and storm events (Majsztrik, 2011; Million et al., 2007; Warsaw et al., 2009). Nutrient concentrations in a greenhouse (crops produced in closed systems with permanent cover) effluent can range from 7.5 to $381 \mathrm{mg} \cdot \mathrm{L}^{-1} \mathrm{NO}_{3}-\mathrm{N}, 0.9$ to $47 \mathrm{mg} \cdot \mathrm{L}^{-1}$ ammoniacal-nitrogen $\left(\mathrm{NH}_{4}-\mathrm{N}\right)$, and 0.85 to $306 \mathrm{mg} \cdot \mathrm{L}^{-1}$ total $\mathrm{P}$ (Dole et al., 1994; Prystay and Lo, 2001; Roseth and Haarstad, 2010). Runoff volumes from greenhouses production systems vary, depending on container size and spacing, irrigation rates, and whether systems are open or closed, but in general, runoff volumes can range from 4.5 to $12.6 \mathrm{~L} \cdot \mathrm{m}^{-2} \cdot \mathrm{d}^{-1}$ (Majsztrik, 2011; Prystay and Lo 2001). In future studies, more emphasis should be placed on quantifying runoff volumes from production areas, whether greenhouse, container, or field, because compliance with regulations will likely be measured using loading data [nutrient mass (concentration $x$ runoff volume) per unit area per unit time], rather than concentration data alone, because water conservation will likely be a crucial aspect of production management.

Nutrient-rich runoff from nursery and greenhouse production areas is under increased scrutiny from regulators and environmental groups, although according to the Clean Water Act, return flows from irrigated agriculture are considered non-point source contributions to watersheds (U.S. EPA, 2013a). During the past 40 years, regulation of point source nutrient contributors has reduced $\mathrm{N}$ 
and $\mathrm{P}$ loading into water bodies, but these regulations have not adequately protected our nation's surface waters, because many streams, river segments, and lakes remain on the 303(d) list of impaired waters (U.S. EPA, $2013 \mathrm{~b}$ ). Because regulation of point sources has not adequately improved the water quality in many of our surface waters, effluent from all land use types, whether point or nonpoint source, in a watershed may become regulated by individual states and municipalities as is now the case in the Chesapeake Bay watershed (Majsztrik and Lea-Cox, 2013). Shifts in policy within individual states and regions could place additional regulations on agricultural producers to manage production practices to limit irrigation runoff and prevent on-site erosion, because these are the primary mechanisms by which non-point sources of nutrients enter and impair surface waters.

\section{VEGETATION-BASED BEST MANAGEMENT PRACTICES}

Container nursery and greenhouse operations have several best management practices/ strategies available to decrease nutrient-rich runoff, including denitrification walls and vegetated/turfgrass buffer strips for low-flow volumes (Lee et al., 2003; Schipper and Vojvodic-Vukovic, 2001), vegetated ditches for low to moderate volumes (Cooper et al., 2004), and constructed wetlands for moderate to high volumes of runoff (Arnold et al., 1999; Taylor et al., 2006; White et al., 2010). The type of best management practice implemented depends on availability of land for a treatment system, site topography, runoff volume and frequency, and the nature of water flow (e.g., continuous or intermittent), all factors affecting nutrient load in irrigation runoff. Constructed wetland systems provide consistent contaminant removal while being both low maintenance and lower in cost than alternative nutrient treatment technologies (White et al., 2010).

\section{CONSTRUCTED WETLAND REMEDIATION PRINCIPLES}

Contaminant cycling and removal within wetland systems is regulated by microbial and plant communities, the sediment or rootbed substrate, and fluxes within the water column (Kadlec and Wallace, 2008). Bacterial communities metabolize, degrade, and remove contaminants from water flowing through the wetlands. The stems of emergent hydrophytes provide surfaces within the water column for microbial communities to colonize, whereas high-density plantings decrease the rate of water flow through the wetland, enhancing sedimentation. The sediment supports the plant root system, provides surfaces for colonization by bacteria, and enhances ion complexation through redox reactive surfaces (Kadlec and Wallace, 2008). The water column is the link between surface water and the sediment and facilitates transport of chemicals and gases between microbial, plant, and animal communities (Kadlec and Wallace, 2008).

Wetlands assimilate and transform nutrients through a range of physical and biological mechanisms including microbially mediated processes, chemical networks, volatilization, sedimentation, sorption, plant uptake and senescence, and accretion (Kadlec and Wallace, 2008; Kröger et al., 2007; Pant et al., 2001; White et al., 2011). Increased hydrophyte richness in constructed wetlands improves both wetland function and nutrient processing capacities (Cooper et al., 2004; Engelhardt and Ritchie, 2001; Fraser et al., 2004). Nitrogen is efficiently assimilated in constructed wetlands and released as $\mathrm{N}$ gas through ammonification of organic $\mathrm{N}$, nitrification of ammonia, and denitrification of nitrate (Kadlec and Wallace, 2008). Seasonal depressions of $\mathrm{N}$ removal are likely in most regions in response to reduced plant growth and inhibition of biological processing during cold weather (Arnold et al., 1999; Kadlec and Reddy, 2001; Taylor et al., 2006).

Phosphorus removal is more variable than $\mathrm{N}$ removal. Both saturable and renewable mechanisms control P removal. Phosphorus sorption to mineral soils and storage and cycling within biomass, including both plant uptake and microbial immobilization, are saturable $\mathrm{P}$ removal mechanisms; $\mathrm{P}$ removal facilitated by accretion of decay-resistant biomass into wetland soils and precipitation reactions are considered renewable mechanisms (Kadlec and Wallace, 2008; Pant et al., 2001). When $P$ loading into a wetland systems is below or near its $\mathrm{P}$ assimilation capacity, accretion and precipitation reactions may adequately control $\mathrm{P}$ cycling, but when $\mathrm{P}$ loading rates increase above the wetlandspecific $\mathrm{P}$ assimilation capacity, harvest and removal of plant biomass or saturated sediments may be necessary to limit internal cycling of $\mathrm{P}$ within the wetland.

Plant harvests from wetlands can shortcircuit the internal $P$ cycle but can be difficult (for rooted hydrophytes), result in stand damage if performed too frequently (Kim and Geary, 2001), and be costly both in terms of labor and biomass disposal (Kadlec and Wallace, 2008). The only instance whereby harvest might be considered a sustainable $\mathrm{P}$ control mechanism is when floating plants are harvested. Constructed wetlands are used to treat container nursery or greenhouse irrigation runoff, because irrigation frequency within container production permits consistent flows into constructed wetlands compared with the more punctuated flows in agricultural runoff. Removal of $\mathrm{N}$ and $\mathrm{P}$ is heavily influenced by the hydrologic regime of the constructed wetland (Tanner and Kadlec, 2013). Continuous flows support sustained biological activity within the wetland system compared with flood and pulse flows (Diaz et al., 2012; Tanner and Kadlec, 2013).

Constructed wetlands are sized based on site-specific considerations, which include site geography, nutrient loading rates (nutrient concentration times volume of runoff per unit production area), and desired effluent end points. The planned treatment capacity or hydraulic retention time (HRTs) of a constructed wetland is the time that water remains within treatment cells. Typical HRTs range from 3 to $5 \mathrm{~d}$, but if average production effluent contains higher (greater than $50 \mathrm{mg} \cdot \mathrm{L}^{-1}$ $\mathrm{NO}_{3}-\mathrm{N}$ and greater than $6 \mathrm{mg} \cdot \mathrm{L}^{-1}$ total $\mathrm{P}$ ) concentrations of nutrients, designed HRT could increase to greater than $10 \mathrm{~d}$ to meet target remediation end points.

The majority of constructed wetlands used for agricultural wastewater treatment are surface-flow constructed wetlands because maintenance of subsurface-flow (SSF) constructed wetlands to prevent clogging of the porous substrate is costly (O'Geen et al., 2010). However, as regulations for $P$ entering surface waters become more stringent, the use of SSF wetlands for treatment of agricultural effluent may increase, because SSF constructed wetlands are better suited for effective P removal (White et al., 2011).

Before discussing constructed wetlands in detail, one should note that nutrient loading from greenhouse and nursery production sources into constructed wetland systems is quite variable and change both with season and cultural practices (e.g., fertilization and irrigation). Much of the data presented are averages over time; thus, the variability (SE) associated with the mean data presented in Tables 1 and 2 reflects a variety of factors, not just treatment efficacy.

\section{SURFACE-FLOW CONSTRUCTED WETLANDS}

In surface-flow (SF) constructed wetlands, water flows above the sediment or media surface, which is typically a clay or native soil with a subtending hardpan that is relatively impervious to water penetration (Fig. 1). Nitrogen removal within a SF constructed wetland at a nursery in south Georgia, U.S., averaged $95 \%$ to $71 \%$ total $\mathrm{N}$ removal from production effluent from March to September and December to February, respectively, during a 3-year study (Taylor et al., 2006). White et al. (2010) also monitored nutrient dynamics in the same wetland system on a daily basis during the spring (March, April, and May) for 3 years $(2003,2005$, and 2006) as the potential for export of $\mathrm{N}$ and $\mathrm{P}$ during the peak fertilization of crops during spring was a concern. Consistent $\mathrm{N}$ removal was reported, although $\mathrm{N}$ concentrations entering the wetland during the spring were 2.6 times higher on average than those entering the wetland on an annual basis (White et al., 2010). The percent of $\mathrm{N}$ removed annually $(90 \%)$ was similar to that removed during the spring (82\%) (Table 1). Longer HRTs increased the percent of $\mathrm{N}$ removed; during the spring study, $14 \%$ more $\mathrm{N}$ was removed with a 5.5-d HRT compared with a 3.5-d HRT (White et al., 2010).

In a smaller-scale study conducted in British Columbia, Canada, wastewater from greenhouse vegetable production was treated using pilot-scale surface flow constructed wetlands established with 15 - or 30-cm depths 
Table 1. Concentration, ${ }^{\mathrm{z}}$ load, and percent removal of nitrogen $(\mathrm{N})$ and phosphorus $(\mathrm{P})$ in vegetated surface flow constructed wetlands as influenced by hydraulic retention time (HRT), water depth, and wetland size.

\begin{tabular}{|c|c|c|c|c|c|c|c|c|c|c|}
\hline Location & $\begin{array}{c}\text { Time } \\
\text { (months) }\end{array}$ & Nutrient & $\begin{array}{l}\text { Size } \\
\left(\mathrm{m}^{2}\right)\end{array}$ & $\begin{array}{l}\text { HRT } \\
\text { (d) }\end{array}$ & $\begin{array}{l}\text { Depth } \\
(\mathrm{cm})\end{array}$ & $\begin{array}{l}\text { Influent load } \\
\left(\mathrm{mg} \cdot \mathrm{m}^{-2} \cdot \mathrm{d}^{-1}\right)\end{array}$ & $\begin{array}{l}\text { Effluent load } \\
\left(\mathrm{mg} \cdot \mathrm{m}^{-2} \cdot \mathrm{d}^{-1}\right)\end{array}$ & $\begin{array}{l}\text { Influent concn } \\
\left(\mathrm{mg} \cdot \mathrm{L}^{-1}\right)\end{array}$ & $\begin{array}{l}\text { Effluent concn } \\
\left(\mathrm{mg} \cdot \mathrm{L}^{-1}\right)\end{array}$ & $\begin{array}{c}\text { Removal } \\
(\%)\end{array}$ \\
\hline \multirow{2}{*}{$\begin{array}{l}\text { British Columbia, } \\
\text { Canada }^{y}\end{array}$} & & & 245 & 10 & 30 & $6740 \pm 2800$ & $3370 \pm 2040$ & $223 \pm 92.6$ & $112 \pm 67.5$ & 50 \\
\hline & & & 243 & 10 & 30 & $3000 \pm 2480$ & $2170 \pm 1810$ & $99.3 \pm 81.9$ & $71.8 \pm 60.0$ & 28 \\
\hline \multirow[t]{4}{*}{ Cairo, GA U.S. ${ }^{x}$} & 3 (spring) & $\mathrm{N}$ & 17,806 & 3.5 & 76.2 & $206 \pm 20.4$ & $7.20 \pm 0.80$ & $21.7 \pm 1.8$ & $8.94 \pm 0.86$ & 69 \\
\hline & & & 31,161 & 5.5 & $76.2,20.3^{\mathrm{w}}$ & $206 \pm 20.4$ & $4.82 \pm 0.56$ & $21.7 \pm 1.8$ & $4.92 \pm 0.54$ & 82 \\
\hline & & & 31,161 & 5.5 & $76.2,20.3$ & $12.2 \pm 1.78$ & $0.91 \pm 0.09$ & $2.21 \pm 3.12$ & $1.57 \pm 0.12$ & 9.3 \\
\hline & 36 (annual) & & 31,161 & 5.5 & $76.2,20.3$ & ND & ND & $1.41 \pm 0.55$ & $1.45 \pm 0.47$ & -2.5 \\
\hline
\end{tabular}

${ }^{\mathrm{z}}$ Mean value over time designated $\pm \mathrm{SE}$ of the mean.

y Prystay and Lo (2001), loading rates calculated from HRT, surface area, and concentration data presented in paper.

${ }^{x}$ White et al. (2010; spring study) and Taylor et al. (2006; 3-year, annual study).

${ }^{\text {w}}$ Two-stage constructed wetland, first cell depth $(76.2 \mathrm{~cm})$ and second cell depth $(20.3 \mathrm{~cm})$.

$\mathrm{ND}=$ data not available .

Table 2. Concentration, ${ }^{\mathrm{z}}$ load, and percent removal of nitrogen $(\mathrm{N})$ and phosphorus $(\mathrm{P})$ from nursery in vegetated subsurface flow constructed wetlands as influenced by hydraulic retention time (HRT), water depth, and wetland size.

\begin{tabular}{|c|c|c|c|c|c|c|c|c|c|c|}
\hline Location & $\begin{array}{c}\text { Time } \\
\text { (months) }\end{array}$ & Nutrient & $\begin{array}{l}\text { Size } \\
\left(\mathrm{m}^{2}\right)\end{array}$ & $\begin{array}{l}\mathrm{HRT} \\
\text { (d) }\end{array}$ & $\begin{array}{l}\text { Depth } \\
\text { (cm) }\end{array}$ & $\begin{array}{l}\text { Influent load } \\
\left(\mathrm{mg} \cdot \mathrm{m}^{-2} \cdot \mathrm{d}^{-1}\right)\end{array}$ & $\begin{array}{l}\text { Effluent load } \\
\left(\mathrm{mg} \cdot \mathrm{m}^{-2} \cdot \mathrm{d}^{-1}\right)\end{array}$ & $\begin{array}{l}\text { Influent concn } \\
\left(\mathrm{mg} \cdot \mathrm{L}^{-1}\right)\end{array}$ & $\begin{array}{c}\text { Effluent } \\
\text { concn }\left(\mathrm{mg} \cdot \mathrm{L}^{-1}\right)\end{array}$ & $\begin{array}{c}\text { Removal } \\
(\%)\end{array}$ \\
\hline Clemson, SC U.S.y & & & & 7 & 60 & $336 \pm 346$ & $216 \pm 83.7$ & $8.27 \pm 8.5$ & $5.34 \pm 2.1$ & 37 \\
\hline \multicolumn{11}{|l|}{ New South } \\
\hline \multirow{3}{*}{ Wales, Australia } & & & & 7 & 30 & $157 \pm 19.4$ & $7.14-14.2$ & 10.1 & $0.5-1.0$ & 96 \\
\hline & & $\mathrm{P}$ & 0.22 & 3.5 & 30 & $17.6 \pm 3.50$ & $<1.43$ & 0.58 & $<0.05$ & 90 \\
\hline & & & & 7 & 30 & $8.83 \pm 1.75$ & $<0.71$ & 0.58 & $<0.05$ & 90 \\
\hline \multirow{6}{*}{ Cabrils, Spain ${ }^{w}$} & & & & 16 & 60 & ND & ND & $128 \pm 4.6$ & ND & 93 \\
\hline & & & & 35 & 60 & ND & ND & $128 \pm 14.2$ & ND & 85 \\
\hline & & $\mathrm{P}$ & 4.5 & 7 & 60 & ND & ND & $7.1 \pm 0.5$ & ND & 100 \\
\hline & & & & 9 & 60 & ND & ND & $4.0 \pm 0.3$ & ND & 98 \\
\hline & & & & 16 & 60 & ND & ND & $6.1 \pm 0.3$ & ND & 73 \\
\hline & & & & 35 & 60 & ND & ND & $5.0 \pm 0.2$ & ND & 46 \\
\hline
\end{tabular}

${ }^{2}$ Mean value over time designated \pm SE of the mean.

${ }^{y}$ White et al. (2011), October through March, before calcined clay saturated with phosphorus.

${ }^{x}$ Huett et al. (2005), subsurface flow wetland lined with basaltic gravel.

"Narváez et al. (2011), subsurface flow wetland lines with granite and red volcanic pozzolan.

$\mathrm{ND}=$ data not available, not published.

(Prystay and Lo, 2001). Nutrient concentrations flowing into the constructed wetlands were high $\left(223 \mathrm{mg} \cdot \mathrm{L}^{-1} \mathrm{~N}\right.$ and $99.3 \mathrm{mg} \cdot \mathrm{L}^{-1} \mathrm{P}$; Table 1). Nitrogen concentrations in wetland effluent were reduced equally by $\approx 50 \%$, regardless of cell depth. However, $\mathrm{P}$ removal efficacy was influenced by cell depth with shallower cells facilitating two times as much $(54 \%)$ removal as the $30-\mathrm{cm}$ cells $(28 \%)$ (Prystay and Lo, 2001; Table 1). In the Taylor et al. (2006) study, P was exported rather than assimilated by the constructed SF wetland on an annual basis. White et al. (2010) reported $8.5 \%$ and $9.3 \% \mathrm{P}$ removal for the same twostage SF wetland with 3.5- and 5.5-d HRTs, respectively. The $\mathrm{P}$ removal reported was likely the result of plant uptake, because plants in the constructed wetland were actively growing and gaining biomass during the experimental period and could serve as a sink for both $\mathrm{N}$ and $\mathrm{P}$. In contrast, $\mathrm{P}$ export from the constructed wetland during the last year of the 3-year Taylor et al. study was likely the result of a variety of factors, including inflow $\mathrm{P}$ concentrations lower than the mean equilibrium $\mathrm{P}$ concentrations of the wetland $(\mathrm{P}$ concentrations below this mean equilibrium value typically result in desorption of $\mathrm{P}$ from wetland sediments), desorption of $\mathrm{P}$ from the clay lining the wetland cells in response to changes in $\mathrm{pH}$ or dissolved oxygen at the sediment water interface, and release of $\mathrm{P}$ resulting from internal cycling processes such as decay of senescing plant matter.

Prystay and Lo (2001) recommended a multistage design with an unplanted pretreatment basin to facilitate $\mathrm{P}$ removal and planted surface flow cells for $\mathrm{N}$ removal. The retention time examined by Prystay and Lo (2001) was twice that of both Taylor et al. (2006) and White et al. (2010); however, the influent $\mathrm{N}$ concentration was 11 times higher, whereas loading rates were 16 to 33 times higher, depending on cell depth (Table 1), and the influent $P$ concentration was 45 times higher, whereas $P$ loading rates were 123 to 246 times higher, depending on cell depth. Despite the longer retention times in the Prystay and Lo (2001) study, the pilot-scale cells did not adequately remove $\mathrm{N}$ and $\mathrm{P}$. Additional stages of treatment cells or a treatment train were needed to extend the retention time of effluent within this system to adequately remove both $\mathrm{N}$ and $\mathrm{P}$ from the nutrient-rich greenhouse effluent (Prystay and Lo, 2001).

Although the $\mathrm{N}$ concentration in effluent leaving the first stage (3.5 d HRT) of the constructed wetland in the White et al. (2010) study would meet drinking water requirements $\left(10 \mathrm{mg} \cdot \mathrm{L}^{-1} \mathrm{NO}_{3}-\mathrm{N}\right.$ or less), the ecological health of surface waters receiving this effluent could be degraded. The $\mathrm{N}$ concentrations were well above the $0.5-\mathrm{mg} \cdot \mathrm{L}^{-1} \mathrm{~N}$ concentration that is recognized to minimize eutrophication of receiving waters (Khan and Ansari, 2005). Depending on the stringency of the regulations proposed, longer retention times in SF constructed wetlands may be required to adequately cleanse nursery effluent, which would also increase a system's size and, therefore, land requirements and cost.

The metric (concentration or load) that regulators will use to moderate the impacts of nutrient-laden runoff is uncertain. In the two most recent cases in which regulations were imposed in an effort to protect water resources, the Florida numeric nutrient criterion used concentration-based end points, 
whereas the Chesapeake Bay used total maximum daily loads (TMDLs) (Majsztrik and Lea-Cox, 2013; Obreza et al., 2011; U.S. EPA, 2010). Concentration-based metrics alone are poor end points for protection of ecosystem health. For example, if one regulates effluent concentration alone, those who have to alter practices to comply with the regulation may simply dilute effluent to meet the concentration requirement rather than alter fertilization and irrigation practices to reduce mass of nutrients and volume of water leached from production areas. A TMDL-based regulatory criterion would encourage changes in practice that would help conserve water resources while limiting nutrient impacts.

\section{SUBSURFACE-FLOW CONSTRUCTED WETLANDS}

In SSF constructed wetlands, water flows directly through media and is not generally visible (Fig. 2). Subsurface-flow constructed wetlands have been used to treat nutrient-rich wastewaters (Headley et al., 2001) and effectively facilitate nutrient removal, especially

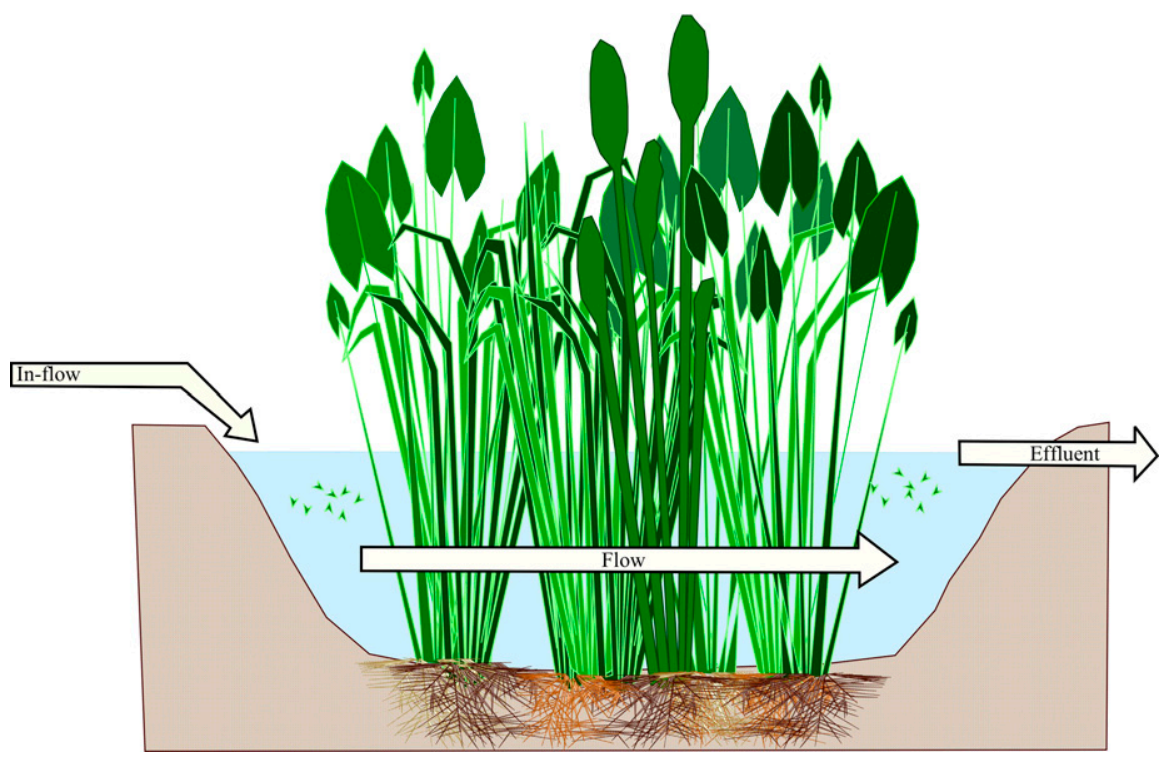

Fig. 1. Water flow path of a surface-flow (free water surface) constructed wetland.

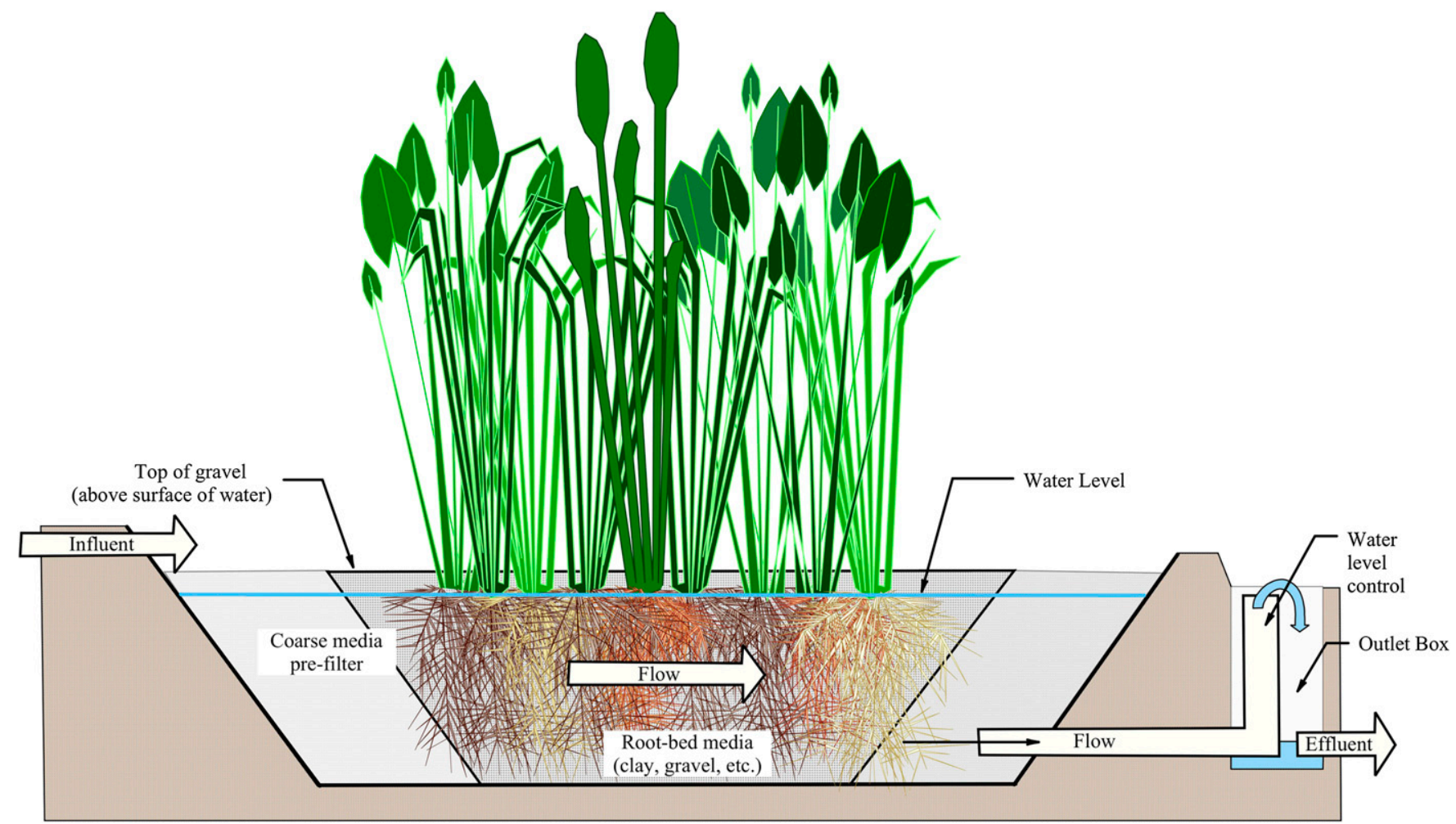

Fig. 2. Water flow path through a subsurface flow constructed wetland. 
White et al. (2011) reported consistent removal of $P$ from simulated nursery effluent in a two-stage surface flow to subsurface flow constructed wetland trial. Phosphorus was not exported from the system for 6 months, at which time the root-bed substrate (a calcined clay) became saturated. Average P removal before the substrate saturated was $33 \%$ for the 4 -d HRT treatment cells and 38\% for 7-d HRT treatment cells (Table 2). Huett et al. (2005) conducted a similar study comparing retention time of water in the wetland cells; however, P-loading rates were 30 times lower and reported removal efficacy averaged $90 \%$ for both the 3.5- and 7-d retention times with $\mathrm{P}$ concentrations in effluent averaging less than $0.05 \mathrm{mg} \cdot \mathrm{L}^{-1}$ phosphorus (Table 2 ). Nitrogen concentrations were also reduced from $10.1 \mathrm{mg} \cdot \mathrm{L}^{-1}$ to less than $1 \mathrm{mg} \cdot \mathrm{L}^{-1} \mathrm{~N}$ in the treatment wetlands, regardless of the HRT. Narváez et al. (2011) evaluated removal of $\mathrm{N}$ and $\mathrm{P}$ from nursery effluent using both singlestage and two-stage, constructed SSF wetland systems. Treatment efficacy for $\mathrm{N}$ was relatively consistent ( $85 \%$ to $99 \%$ ) over the four retention times examined (Table 2) without regard to stages of treatment or substrate within the cells. However, P removal decreased over time, and the authors suggested that clogging or saturation of the substrate contributed to this decline in $\mathrm{P}$ removal from $99 \%$ to $46 \%$ over a 28 -d period.

Both surface and subsurface flow constructed wetlands require committing land for remediation purposes that could otherwise be used for production. Now, most growers do not have the capacity or are not willing to allocate land in this manner. Therefore, an alternative to these more traditional technologies is needed.

\section{FLOATING TREATMENT WETLANDS}

Floating treatment wetlands (FTWs) are a relatively new wetland technology that have gained acceptance in both the scientific and regulatory world over the past 5 years (Tanner and Headley, 2011; Wanaliesta et al., 2012;

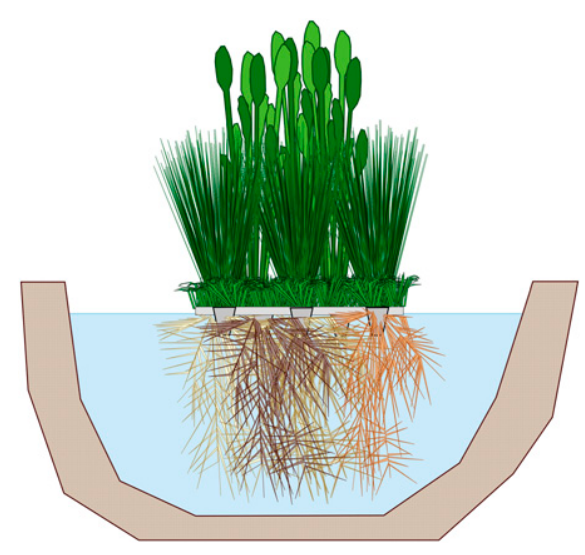

Fig. 3. Cross-section of floating treatment wetland established in a pond or canal. Plant crowns are supported by solid-core foam or other buoyant matrix facilitating survival of semiaquatic and aquatic species.
White and Cousins, 2013). One advantage of FTWs is that they can be installed in existing retention ponds or drainage canals to facilitate nutrient removal. The Florida Department of Environmental Protection has accepted FTWs as a best management practice with a $12 \%$ concentration $(\mathrm{N}$ and $\mathrm{P}$ ) reduction credit for nutrient removal in stormwater ponds (Wanaliesta et al., 2012).

Remediation of $\mathrm{N}$ and $\mathrm{P}$ within FTWs is accomplished using the same biological and chemical processes that make traditional surface and subsurface flow constructed wetlands effective. The plants in FTW are placed in a buoyant substrate that keeps the plant crown above the water surface rather than planting the hydrophyte in the sediment or a substrate and submerging the crown in the water column or the plant roots within the soil (Fig. 3). This enables use of a greater variety of plants in the FTW rather than only hydrophytic species. The root systems of the plants placed in the FTWs extend into the water column from 20 to $80 \mathrm{~cm}$, depending on plant species, and provide very large surface areas for bacterial communities to colonize. Extensive root systems in the water column provide a larger surface area for intercepting sediment, absorbing nutrients, and releasing soluble carbon and other bioactive compounds that enhance removal of contaminants (Tanner and Headley, 2011; White et al., 2009). Although FTWs are tolerant of fluctuating water levels, a minimum water depth of $1 \mathrm{~m}$ should be observed to limit potential for plants rooting into sediments.

White and Cousins (2013) conducted experiments with FTWs in 2008 and 2009 examining $\mathrm{N}$ and $\mathrm{P}$ removal at two loading rates. Influent concentrations during the 2008 study were $0.85 \pm 0.32 \mathrm{mg} \cdot \mathrm{L}^{-1} \mathrm{~N}$ and $0.08 \pm$ $0.02 \mathrm{mg} \cdot \mathrm{L}^{-1} \mathrm{P}$ and in 2009 were $1.88 \pm 0.38$ $\mathrm{mg} \cdot \mathrm{L}^{-1} \mathrm{~N}$ and $0.22 \pm 0.05 \mathrm{mg} \cdot \mathrm{L}^{-1} \mathrm{P}$. Nitrogen concentrations in effluent leaving the smallscale $\left(1.5 \mathrm{~m}^{2}\right.$ and $3.0 \mathrm{~m}^{2} ; 95 \%$ cover $)$ were reduced by $84 \%$ in 2008 , down to $0.14 \pm 0.04$ $\mathrm{mg} \cdot \mathrm{L}^{-1} \mathrm{~N}$, and by $58 \%$ in 2009 , down to $0.79 \pm 0.3 \mathrm{mg} \cdot \mathrm{L}^{-1} \mathrm{~N}$. Effluent $\mathrm{P}$ concentrations averaged $0.02 \pm 0.01$ and $0.12 \pm 0.03 \mathrm{mg} \cdot \mathrm{L}^{-1} \mathrm{P}$ in 2008 and 2009, respectively, which equated to average $\mathrm{P}$ removal of $75 \%$ in 2008 and $46 \%$ in 2009. Differences in nutrient loading rates, plant uptake of nutrients, and percent coverage of FTW were the primary drivers of nutrient removal from the ponds. Tanner and Headley (2011) reported a 3-fold reduction of dissolved reactive $\mathrm{P}$ and fine suspended particles in treatment systems with 50\% FTW cover. Current recommendations call for $5 \%$ cover on ponds with lower loading rates and up to $10 \%$ cover on ponds with increased loading or mixing (aeration) rates based on economic factors and nutrient removal efficacy (Wanaliesta et al., 2012). Increased coverage percentages enhance nutrient remediation, but economic considerations usually limit installations with higher percentages of cover.

One option that could enhance the return on investment for FTW systems is their use as an alternative production area using nutrients leached during irrigation events to produce another crop. Potential crops include highvalue food crops (e.g., butterhead lettuce, basil, etc.), although food safety considerations may limit widespread application, or a biomass crop. One factor that must be more thoroughly explored before FTWs are implemented widely as a best management practice for nutrient mitigation is the use of active (harvested) vs. passive (non-harvested) management strategies. To effectively remove nutrients from the aquatic environment and break the internal nutrient cycle, the plant material in these systems must be harvested and not permitted to senesce in situ. However, harvest is a labor- and cost-intensive process, and unless the materials harvested can be used for another purpose, it is not likely to be widely adopted as a management practice for floating treatment wetlands.

\section{CONCLUSIONS}

The three treatment wetland technologies discussed range in applicability for small- to large-scale production facilities. Land availability, nutrient loading from production runoff, regulatory pressure, and financial resources will influence the degree to which any of the technologies will be adopted. These technologies are accepted treatment technologies that are adaptable to a variety of operation types and runoff scenarios and should be considered when specialty crop producers need best management practices to help mitigate nutrient-rich effluent.

\section{Literature Cited}

Arnold, M.A., B.J. Lesikar, A.L. Kenimer, and D.C. Wilkerson. 1999. Spring recovery of constructed wetland plants affects nutrient removal from nursery runoff. J. Env. Hort. 17: 5-10.

Conley, D.J. 2000. Biogeochemical nutrient cycles and nutrient management strategies. Hydrobiol. 410:87-96.

Conley, D.J., H.W. Paerl, R.W. Howarth, D.F. Boesch, S.P. Seitzinger, K.E. Havens, C. Lancelot, and G.E. Likens. 2009. Controlling eutrophication: Nitrogen and phosphorus. Science 32:10141015.

Cooper, C.M., M.T. Moore, E.R. Bennett, S. Smith, J.L. Farris, C.D. Milam, and F.D. Shields, Jr. 2004. Innovative uses of vegetated drainage ditches for reducing agricultural runoff. Water Sci. Technol. 49:117-123.

Diaz, F.J., A.T. O'Geen, and R.A. Dahlgren. 2012 Agricultural pollutant removal by constructed wetlands: Implications for water management and design. Agr. Water Mgt. 104:171-183.

Dole, J.M., J.C. Cole, and S.L. von Broembsen. 1994. Growth of poinsettieas, nutrient leaching, and water-use efficiency respond to irrigation methods. HortScience 29:858-864.

Elser, J.J., E.S.M. Bracken, E.E. Cleland, D.S. Gruner, W.S. Harpole, H. Hillebrand, J.T. Ngai, E.W. Seabloom, J.B. Shurin, and J.E. Smith. 2007. Global analysis of nitrogen and phosphorus limitation of primary producers in freshwater, marine and terrestrial ecosystems. Ecol. Lett. 10:1135-1142.

Engelhardt, K.A.M. and M.E. Ritchie. 2001. Effects of macrophyte species richness on wetland ecosystem functioning and services. Nature 411:687-689. 
Fraser, L.H., S.M. Carty, and D. Steer. 2004. A test of four plant species to reduce total nitrogen and total phosphorus from soil leachate in subsurface wetland microcosms. Bioresour. Technol. 94:185-192.

Headley, T.R., D.O. Huett, and L. Davison. 2001. The removal of nutrients from plant nursery irrigation runoff in subsurface horizontal-flow wetlands. Water Sci. Technol. 44:77-84.

Huett, D.O., S.G. Morris, G. Smith, and N. Hunt 2005. Nitrogen and phosphorus removal from plant nursery runoff in vegetated and unvegetated subsurface flow wetlands. Water Res. 39:3259-3272.

Kadlec, R. and S.D. Wallace. 2008. Treatment wetlands. 2nd Ed. CRC Press, Boca Raton, FL.

Kadlec, R.H. and K.R. Reddy. 2001. Temperature effects in treatment wetlands. Water Environ. Res. 73:543-557.

Khan, F.A. and A.A. Ansari. 2005. Eutrophication: An ecological vision. Bot. Rev. 71:449-482.

Kim, S.Y. and P.M. Geary. 2001. The impact of biomass harvesting on phosphorus uptake by wetland plants. Water Sci. Technol. 144:61-67.

Kröger, R., M.M. Holland, M.T. Moore, and C.M. Cooper. 2007. Plant senescence: A mechanism for nutrient release in temperate agricultural wetlands. Environ. Pollut. 146:114-119.

Lee, K.H., T.M. Isenhart, and R.C. Schultz. 2003. Sediment and nutrient removal in an established multi-species riparian buffer. J. Soil Water Conserv. 58:1-8.

Lillie, R. and J. Mason. 1983. Limnological characteristics of Wisconsin lakes. Wisconsin Department of Natural Resources Tech. Bull. \#138. Madison, WI.

Majsztrik, J.C. 2011. Modeling nitrogen, phosphorus and water dynamics in greenhouse and nursery production systems. PhD diss., Univ. of Maryland, College Park, MD. Abstr. 3461553.

Majsztrik, J.C. and J.D. Lea-Cox. 2013. Water quality regulations in the Chesapeake Bay: Working to more precisely estimate nutrient loading rates and incentivize best management practices in the nursery and greenhouse industry. HortScience 48:1097-1102.

Million, J., T. Yeager, and J.P. Albano. 2007. Consequences of excessive overhead irrigation on runoff during container production of sweet viburnum. J. Environ. Hort. 25:117-125.

Narváez, L., C. Cunill, R. Cáceres, and O. Marfà. 2011. Design and monitoring of horizontal subsurface-flow constructed wetlands for treating nursery leachates. Bioresour. Technol. 102:6414-6420.

Obreza, T., M. Clark, B. Boman, T. Borisova, M Cohen, M. Dukes, T. Frazer, E. Hanlon, K. Havens, C. Martinez, K. Migliaccio, S. Shukla, and A. Wright. 2011. A guide to EPA's numeric nutrient water quality criteria for Florida. UF IFAS Extension. SL316. 20 Nov. 2012. <http:// edis.ifas.ufl.edu/ss528>.

O'Geen, A.T., R. Budd, J. Gan, J.J. Maynard, S.J. Parikh, and R.A. Dahlgren. 2010. Mitigating nonpoint source pollution in agriculture with constructed and restored wetlands. Adv. Agron. 108:1-76.

Pant, H.K., K.R. Reddy, and E. Lemon. 2001. Phosphorus retention capacity of root bed media of sub-surface flow constructed wetlands. Ecol. Eng. 17:345-355.

Prystay, W. and K.V. Lo. 2001. Treatment of greenhouse wastewater using constructed wetlands. J. Environ. Sci. Health B 36:341353.

Rosengrant, M.W. and C. Ringler. 1998. Impact of food security and rural development of transferring water out of agriculture. Water Policy 1:567-586.

Roseth, R. and K. Haarstad. 2010. Pesticide runoff from greenhouse production. Water Sci. Technol. 61:1373-1381.

Schipper, L.A. and M. Vojvodic-Vukovic. 2001. Five years of nitrate removal, denitrification and carbon dynamics in a denitrification wall. Water Res. 35:3473-3477.

Seo, D.C., J.S. Cho, H.J. Lee, and J.S. Heo. 2005. Phosphorus retention capacity of filter media for estimating the longevity of constructed wetland. Water Res. 39:2445-2457.

Tanner, C.C. and T.R. Headley. 2011. Components of floating emergent macrophyte treatment wetlands influencing removal of stormwater pollutants. Ecol. Eng. 37:474-486.

Tanner, C.C. and R.H. Kadlec. 2013. Influence of hydrological regime on wetland attenuation of diffuse agricultural nitrate losses. Ecol. Eng. 56:79-88.

Taylor, M.D., S.A. White, S.L. Chandler, S.J. Klaine, and T. Whitwell. 2006. Nutrient management of nursery runoff water using constructed wetland systems. HortTechnology 16:610-614.

U.S. U.S. Environmental Protection Agency. 2010. Draft Chesapeake Bay total maximum daily load.
Section 9. 19 Dec. 2012. <http://www.epa.gov/ reg3wapd/tmdl/ChesapeakeBay/drafttmdlexec. html>.

U.S. Environmental Protection Agency. 2013a. What is nonpoint source pollution? 14 Jan. 2013. <http://water.epa.gov/polwaste/nps/whatis. $\mathrm{cfm}>$.

U.S. Environmental Protection Agency. 2013 b. What is a 303 (d) list of impaired waters? 14 Jan. 2013. <http://water.epa.gov/lawsregs/ lawsguidance/cwa/tmdl/overview.cfm>.

Vohla, C., R. Alas, K. Nurk, S. Baatz, and Ü. Mander. 2007. Dynamics of phosphorus, nitrogen and carbon removal in a horizontal subsurface flow constructed wetland. Sci. Total Environ. 380:66-74.

Wanaliesta, M.P., N.-B. Chang, M. Chopra, Z. Xuan, K. Islam, and Z. Marimon. 2012. Floating wetland systems for nutrient removal in stormwater ponds. Final report. FDOT Project BDK78 985-01. 22 Jan. $2013<$ http://www. dep.state.fl.us/water/nonpoint/docs/nonpoint/ final-report-ucf-fdot-beemats.pdf $>$.

Warsaw, A.L., R.T. Fernandez, B.M. Cregg, and J.A. Andresen. 2009. Container-grown ornamental plant growth and water runoff nutrient content and volume under four irrigation treatments. HortScience 44:15731580 .

White, S.A. and M.M. Cousins. 2013. Floating treatment wetland aided remediation of nitrogen and phosphorus from simulated stormwater runoff. Ecol. Eng. (Submitted).

White, S.A., M.D. Taylor, J.P. Albano, S.J. Klaine, and T. Whitwell. 2011. Phosphorus retention in lab and field-scale subsurface-flow wetlands treating plant nursery runoff. Ecol. Eng. 37: 1968-1976.

White, S.A., M.D. Taylor, S.L. Chandler, S.J. Klaine, and T. Whitwell. 2010. Remediation of nitrogen and phosphorus from nursery runoff during the spring via free water surface constructed wetlands. J. Environ. Hort. 28:209217.

White, S.A., B.C. Seda, M.M. Cousins, S.J. Klaine, and T. Whitwell. 2009. Nutrient remediation using vegetated floating mats. Proc. of SNA Res. Conf. 54:39-43.

Wight, D.A. and P. Welbourn. 2002. Environmental Toxicology. Cambridge environmental chemistry series. Cambridge University Press. Cambridge, UK. p. 249-315. 